\title{
„MYSTERIUM LUNAE" W EKLEZJOLOGII STAROŻYTNEGO KOŚCIOŁA
}

\section{SYMBOLIKA NATURY}

W bogatym i barwnym języku symboliki eklezjologicznej starożytnego chrześcijaństwa zajmuje swoje poczesne miejsce figura księżyca, pojmowana jako symbol Kościoła. Mówi się o "tajemnicy księżyca” mysterium lunae, odnoszonej do tajemnicy Chrystusa i Kościoła, a także do obrazu stanu moralnego wspólnoty Kościoła, której udziałem jest ciągła dialektyka konfrontowania „światła z ciemnością". Na tę tematykę otwierał wyznawców Chrystusa pierwszych stuleci przede wszystkim fakt, że nów księżyca po wiosennym przesileniu dnia i nocy był związany z obchodzeniem najważniejszego w Kościele wydarzenia zbawczego, jakim jest Pascha. Nie bez znaczenia pozostawało tu również dziedzictwo mentalności i kultury starożytnej z charakterystycznymi intuicjami natury religijnej i otwarciem na język symbolu, a z drugiej strony, obecność tegoż tematu w metaforyce biblijnej. To wszystko tworzyło wokół niego

* Ks. Tomasz Kaczmarek, dr hab. adiunkt w Zakładzie Patrologii i Antyku Chrześcijańskiego na Wydziale Teologicznym UMK. Współpracownik Kongregacji Spraw Kanonizacyjnych w Watykanie. 
szczególną atmosferę, łączoną z przeżywaniem i wyrażaniem tajemnicy odkupienia. Jest więc czymś naturalnym, że w misteriach chrześcijańskich temat ten musiał znaleźć swój właściwy rezonans.

Jak bogatą jest ta tematyka, może świadczyć wnikliwe studium jeszcze z lat trzydziestych ubiegłego stulecia, wówczas pionierskie, którego autorem był o. Hugo Rahner SJ, poświęcone eklezjologii pierwszych stuleci opisywanej językiem symbolu ${ }^{1}$. Hugo Rahner rozpatrywał w nim motyw mysterium lunae na trzech płaszczyznach, skupiając się kolejno na starożytnej symbolice księżyca dla wyrażenia stanu Kościoła „umierającego", "odradzającego się" oraz rozbłyskującego w splendorze okazywania się w nim zwycięstwa Bożej miłości. Walor tych analiz powiększa głębokie ich osadzenie w ówczesnej kulturze, co umożliwiała niezwykła erudycja tegoż bawarskiego teologa i znawcy kultury antycznej.

Gdy przychodzi stwierdzić, że problematyka ta jest raczej nieznana w teologicznej literaturze polskojęzycznej ${ }^{2}$, tym bardziej narzuca się stosowność przybliżenia jej przynajmniej w bardzo ograniczonych ramach niniejszego artykułu. Nasza uwaga skupi się najpierw na skrótowym zarysowaniu tła problematyki w mentalności starożytnej, by ukazać, jak stopniowo w chrześcijaństwie pogłębia się refleksja nad tym tematem, który został umiejętnie podjęty w ramach przesłania misyjnego chrześcijaństwa wobec kultury pogańskiej. Chodziło o powrót na inny sposób do symboliki natury, tak żywo obecnej w mentalności świata starożytnego, by poprzez jej nową interpretację kierować teraz uwagę neofitów na tajemnicę Chrystusa i Kościoła ${ }^{3}$.

\section{INTUICJE RELIGIJNE ŚWIATA ANTYCZNEGO}

Zarówno w astronomii starożytnego Wschodu, jak i w ludowym odczuciu religijnym, księżyc miał większe znaczenie niż słońce. Prymitywne odmierzanie czasu opierało się bowiem wszędzie na zmianach księżyca, ponieważ jego fazy były - stosownie do możliwości poznaw-

${ }^{1}$ H. Rahner, Symbole der Kirche. Die Ekklesiologie der Väter, Salzburg 1935, tłum. wł.: L'ecclesiologia dei Padri. Simboli della Chiesa, Roma 1971 [o. Hugo Rahner był starszym bratem Karola, również z Zakonu Jezuitów, prekursora idei odnowy soborowej].

2 Sygnalizuje ją autor w: "Seges ecclesiae". Eklezjalny wymiar męczeństwa w nauczaniu św. Augustyna, Toruń 2010, s. 61-63; zob. także K. Zalewska-Lorkiewicz, Księżyc, EK 10, kol. 125-127 (wraz z bibliografią).

${ }^{3}$ Por. J. M. Dermott, Lune - symbolisme religieux, DSAM [Dictionnaire de spiritualité ascétique et mistique, Paris 1932-] 9, kol. 1192. 
czych starożytnego człowieka - obiektywną miarą czasu. Stopniowo stawał się po prostu instrumentem mierzenia czasu, co znajduje wyraz nawet w jego indogermańskiej nazwie, w której jest ukryty rdzeń me, tj. „mierzyć” (mena, men, mensis) ${ }^{4}$. Księżyc rządzi wszystkim, co w kosmosie jest poddane prawu cyklicznej zmiany. Nawet znaki alfabetyczne i tony gamy bywały łączone $\mathrm{z}$ fazami księżyca, (próby takie podejmowano na starożytnym Wschodzie), traktując to jako odkrycie tajemnic kosmosu i jego energii. Dzięki swej zmienności księżyc wydawał się być istotą żywą, wkomponowaną w obraz starożytnej astrobiologii ${ }^{5}$. Gdy przez trzy dni nie pojawiał się na niebie, zdawało się jakoby umarł. Potem powstawał do nowego życia i rósł aż do osiągnięcia pełni, aby znowu znikać i po niedługiej zwłoce na nowo rozpoczynać swój cykl zmian. To skłaniało, by sądzić, że księżyc określa rytm życia, a z czasem zaczęto widzieć w nim także źródło wszelkiego życia i wszelkiej płodności. Według powszechnej ludowej obserwacji, fazy księżyca decydują o deszczach, a tym samym o rozwoju wszelkiej wegetacji. Księżycowi przypisywano także wpływ na rozmnażanie się ludzi i zwierząt, chociażby na podstawie $\mathrm{z}$ dawien dawna obserwowanego oddziaływania księżyca na organizm kobiecy ${ }^{6}$.

Bogaty świat wyobrażeń dotyczących księżyca nie jest wielkością samoistna, pozostaje bowiem w najściślejszym związku z mitologią słońca, astralnego brata i małżonka Selene, księżyca jako bóstwa żeńskiego. W mentalności greckiej funkcjonował obraz ognistych strzał miotanych przez Heliosa, boga Słońce, w przeciwieństwie do łagodnego, przyjemnego światła Selene. Ona przechwytuje palące promienie słońca i złagodzone przekazuje dalej. Nie ma własnego światła, co już, choć z niejaką niepewnością, stwierdzali starożytni, lecz w kobiecym oddaniu przyjmuje je od Heliosa, aby uczynić je płodnym. Bezustannie krąży nieśmiało i z tęsknotą wokół ukochanego i znika właśnie w chwili, gdy znajdzie się najbliżej niego, słońca. Podczas tej koniunkcji, czyli w nowiu, kiedy wydaje się, że Selene jakby zagasła i umarła, otrzymuje w ślubnym zjednoczeniu z Heliosem swoją siłę płodzącą. Dlatego uważano, np. w Atenach, dzień nowiu księżyca za najbardziej odpowiedni dla zawarcia małżeństwa. I tak Selene stała się macierzyńską zasadą, dobrotliwą pośredniczką między sferami kosmicznymi a ziemią, od której jest oddalona najmniej. Żywi się

${ }^{4}$ Por. D. Forstner, Świat symboliki chrześcijańskiej, Warszawa 1990, s. 97-98.

${ }^{5}$ Por. C. A. Bernard, Teologia simbolica, Roma 1981, s. 44 n.

${ }^{6}$ Por. D. Forstner, dz. cyt., s. 98. 
wodą ziemi i miesza ją z silnymi, suchymi promieniami słońca, i w ten sposób powstaje ciepła i wilgotna woda księżycowa, która według poglądu pitagorejskiego jest źródłem wszelkiego życia. Z niej też bierze się rosa, szczególnie obficie opadająca w jasne noce księżycowe, rosa będąca jakby mlekiem, którym matczyna Luna (łaciński odpowiednik nazwy "Selene”) karmi wszystko, co żyje. Od Arystotelesa i Teofrasta po Cycerona, Plutarcha i Pliniusza, we wszystkich naukach przyrodniczych świata antycznego, w medycznych, rolniczych, astrologicznych podręcznikach i receptach, we wierzeniach ludowych pomieszanych z magią i czarami wyrażano przekonanie, że Selene jest matką wszelkiego życia, władczynią porodów. Decyduje nawet o powstawaniu minerałów, zwłaszcza kamieni szlachetnych, rozwoju pereł w muszlach, kryzysach w chorobach, pomyślnych i niepomyślnych dniach i całym ludzkim losie na ziemi. Luna włada nie tylko jednak życiem, które przemienia. Obszar jej wpływów wyznaczają granice między ciemnym, podlegającym przeznaczeniu regionem ziemi a sferą nieba, gdzie wszystko jest ogniem i światłem, dlatego dusze nieśmiertelne spadły na ciemną ziemię jak iskry ognia czy krople niebiańskiej wody i stale tęsknią za swoją prawdziwą ojczyzną ${ }^{7}$.

Po śmierci sprawiedliwych ich dusze wędrują najpierw w jasną sferę Selene, aby następnie wznieść się w światy jeszcze wyższe. $W$ ten sposób Luna stała się również symbolem nieśmiertelności, szczęścia i ochrony przed złymi demonami, które zamieszkują sfery podksiężycowe. Dlatego też chętnie noszono biżuterię i amulety w formie małych księżyców (nawet u Żydów, por. Iz 3,18) i ceniono je sobie jako okolicznościowe podarunki. Szczęśliwe dzieci nierzadko nazywano „dziećmi księżyca”. Lunula z kości słoniowej, ozdoba w kształcie księżyca, noszona na obuwiu rzymskich patrycjuszy była symbolem dawniejszego pobytu na księżycu i wiary, że po śmierci dusze znowu będą miały księżyc pod nogami, tzn. zamieszkają w jego szczęśliwych regionach. Dzień nowiu już u Homera ma znaczenie religijne. Przede wszystkim jednak człowiek starożytny rozpoznawał w zmiennych formach "ż̇ycia" Luny swój własny los, a z jej bezustannym odnawianiem się wiązał swoją nadzieję na nieśmiertelność. Najgłębszy sens całej symboliki lunarnej tkwi w tym, że każde ziemskie istnienie podlega prawu ustawicznej zmiany, rytmicznemu stawaniu się, że biegunowość jednak wzrostu i życia z jednej strony a przemijania i śmierci z drugiej, jest przezwyciężana przez

7 Por. H. Rahner, Miti greci nell'interpretazione cristiana, Bologna 1971, s. 176-181. 
cykliczne odradzanie się, by w końcu została całkowicie zniesiona przez życie wieczne ${ }^{8}$.

\section{PODJĘCIE TEMATU PRZEZ CHRZEŚCIJAŃSTWO}

Biblia, która dla starożytnego chrześcijaństwa zawsze była niepodważalnym autorytetem nawet co do sformułowań literalnych, wielokrotnie w różnych kontekstach dotyka również tematu księżyca. W wizji stworzenia świata wg Księgi Rodzaju księżyc należy do tych ciał niebieskich, które w zamiarze Stwórcy mają odmierzać czas (Rdz 1, 14). Księżyc jako „mała latarnia” ma władać nocą (Ps 136,9). Jako miara czasu odgrywał ważną rolę w życiu Izraelitów. Dzień nowiu, będący początkiem miesiąca, wyróżniano i uroczyście obchodzono składaniem specjalnych ofiar (Lb 28, 11nn.) i dęciem w trąby (Lb 10, 10; Ps 81, 4). Ten dzień wyznaczał także utrwalone zwyczaje królewskie, posiłki, obrzędy naznaczone charakterem religijnym (1 Sam 20, 5.18.26). Nów siódmego miesiąca był uważany za szczególnie świąteczny ${ }^{9}$. Izrael choć sam otoczony był sąsiedztwem ludów, gdzie panował żywy kult astralny, a w tym kult księżyca jako „królowej nieba”, zachował swą klarowną wizję wszechświata jaką określał objawiony monoteizm. Ujęcie to sprowadzało się, mówiąc w pewnym uproszczeniu, do informacji o zadaniach tego ciała niebieskiego w świecie danym człowiekowi jako jego przestrzeń życia, choć można dostrzec niekiedy i dążenia do poszerzania spojrzenia na księżyc także o treści symboliczne, jak choćby w motywie z Psalmu 72, gdzie stałe odnawianie się księżyca jest obrazem nieprzemijalności królestwa mesjańskiego (Ps 72, 5), albo w Księdze Pieśni nad pieśniami, odwołującej się do pełni księżyca, jako obrazu piękna: oblubienica z tej Pieśni ,jest piękna jak księżyc" (Pnp 6, 10) ${ }^{10}$.

Utrwalanie się od pierwszych pokoleń chrześcijaństwa lektury Pisma świętego „według ducha”, dostrzegającej pod szatą litery tekstu natchnionego treść głębszą, pozwalało na otwieranie się na wymiar symbolu sakralnego kryjącego się w szczególniejszych rzeczach czy nazwach. To dotyczyło tak samo ciał niebieskich, przy jednoczesnym bardzo zdecydowanym odcięciu się od ich ubóstwiania, tak powszechnego w an-

\footnotetext{
${ }^{8}$ Por. D. Forstner, dz. cyt., s. 98.

${ }^{9}$ R. de Vaux, Le Istituzioni dell'Antico Testamento, Torino 1977, s. 190, 454.

${ }^{10}$ Por. D. Forstner, dz. cyt., s. 98 n.
} 
tycznej kulturze pogańskiej ${ }^{11}$. W rzeczywistości interpretacja pod kątem dostrzegania $w$ nich elementu znaku od Boga zachęcała chrześcijan do tego, by dostrzegać w otaczającym ich świecie i wszechświecie odbicie tajemnic Bożych ${ }^{12}$.

W przekonaniu Teofila z Antiochii, biskupa apologety z końca II wieku, słońce przy takiej lekturze nabiera rangi znaku, symbolu (typos) wskazującego na tajemnicę Chrystusa. Księżyc natomiast, który w swoją naturę ma wpisane powiązanie na stałe ze słońcem, odnosi się do człowieka. Te dwa ciała niebieskie jako typoi wprowadzają w "tajemnicę Boga i człowieka". W takim duchu wspomniany autor zachęcał swoich czytelników, by w słońcu i księżycu dostrzegali „wielką tajemnicę”, która tu sprowadza się do wyrażenia obrazu niezmiennego Boga (słońce) i dążącego do Niego ciążącego ciągle zmieniającego się człowieka, który doświadcza wzrastania, pomniejszania się i umierania, by wreszcie u kresu czasów osiągnąć zmartwychwstanie. Jak wyjaśnia św. Teofil, „słońce bowiem jest figurą alegoryczną Boga, a księżyc - człowieka. I jak słońce przewyższa księżyc mocą i jasnością, tak samo Bóg przewyższa rodzaj ludzki. Jak słońce, które zawsze pozostaje pełne i nigdy nie zmniejsza się, tak samo Bóg pozostaje zawsze doskonały i pełen wszelkiej mocy, rozumu, mądrości, nieśmiertelności i wszystkich dóbr. Księżyc natomiast zmniejsza się co miesiąc i traci moc, gdyż jest obrazem człowieka, potem zaś odradza się i wzrasta, by zapowiedzieć sobą przyszłe zmartwychwstanie"13.

W podobnym duchu podejścia do tematu, jeszcze dwa stulecia później, charyzmatyczny katecheta z Jerozolimy, biskup Cyryl (313-386), w katechezie o zmartwychwstaniu głoszonej dla katechumenów będzie widział w fazach księżyca znak zamierzony przez Stwórcę, by kierował myśl człowieka na prawdę o zmartwychwstaniu ciał. To zjawisko astronomiczne przybiera wprost rangę dowodu na zmartwychwstanie, jaki dostarczają każdego miesiąca ciała niebieskie. Zanikanie widoku księżyca, by następnie $w$ regularnych fazach ukazać swą pełnię światła, powinno uświadamiać ludziom wyrosłym w kulturze greckiej, w której zmartwychwstanie było redukowane do dziedziny absurdu, że przywrócenie do życia zmarłego ciała nie koliduje z logicznym rozumowaniem. Fazy

${ }^{11}$ Zob. m.in. Arystydes, Apologia 6, 3, BAC [Biblioteca de Autores Cristianos, Madrid 1945-] 116, s. 121; Tacjan, Mowa przeciw Grekom 9, 10, BAC 116, s. 584 n.

${ }^{12}$ Por. J. M. Dermott, Lune - symbolisme releigieux, DSAM 9, kol. 1192.

${ }^{13}$ Teofil z Antiochii, Do Auktolika, II, 15, BAC 116, s. 805. Zob. H. Rahner, Miti greci nell'interpretazione cristiana, s. $182 \mathrm{n}$. 
bowiem księżyca nieustannie ilustruja, że istota ożywiona, - a jest nią także księżyc - która weszła w doświadczenie zamierania, może istnieć w swojej pełni na nowo. Zmartwychwstanie ma w taki sposób swoje odwołanie do realnego świata; posiada swoje analogie w przyrodzie, a tym są fazy księżyca. Był to argument dla ówczesnych tym mocniejszy, że w ich przekonaniu, zgodnie ze stanem wiedzy astronomicznej, fazy księżyca oznaczały jego realne obumieranie i ożywanie na nowo. Na podsumowanie tej argumentacji Cyryl konstatuje: „Bóg tak urządził świat, byś człowiecze [...] nie zapomniał o zmartwychwstaniu, lecz uwierzył, iż to co widzisz w księżycu, stanie się i z tobą"14.

\section{ORYGENES: MISTYKA KOSMOSU}

„Wielka tajemnica” Chrystusa i Kościoła, o której pisał Apostoł Paweł w Liście do Efezjan (Ef 5,32), która inspirowała bpa Teofila z Antiochii do odczytania jej symboliki w słońcu i księżycu, pozwoliła Orygenesowi (185-254) odsłonić tutaj wprost treści mistyczne, które dotyczą nierozdzielnej więzi istniejącej między Chrystusem i Kościołem, co później wejdzie już na trwałe do dziedzictwa tradycji teologicznej w zachodniej patrystyce. Ten aleksandryjski teolog, uważany za największego erudytę swojego $\mathrm{czasu}^{15}$, podejmując obecny już w tradycji teologicznej temat „,wielkiej tajemnicy” łączonej z figurą słońca i księżyca, nadał mu zupełnie nowy kierunek i głębię. Zgodnie z wizjami filozoficznymi i astronomicznymi swoich czasów, Orygenes sytuuje księżyc w "przestrzeni czystej”, poza sferami „ognia niebieskiego”, wyznaczonej mu przez Stwórcę. Tam przemierza swoją drogę w „świętym milczeniu”16 i wraz z gwiazdami wykonuje ",taniec, którym raduje wszechświat"17. Kultura grecka i mistyka kosmosu skłaniały go, by przypisywać ciałom niebieskim swojego rodzaju tajemnicze $\dot{z} y c i e^{18}$, mimo, że jest świadomy, iż nie znajduje w tej sprawie

${ }^{14}$ Cyryl Jerozolimski, Katechezy przedchrzcielne i mistagogiczne - Katecheza XVIII, 10, BOK [Biblioteka Ojców Kościoła, Kraków 1992-] 14, s. 303.

${ }^{15}$ J. Daniélou, Origene, Il Genio del Cristianesimo, Roma 1991, s. 9 nn.

${ }^{16}$ Orygenes, Komentarz do św. Jana 13, 40, GCS [Die griechischen christlichen Schriftsteller der ersten drei Jahrhunderte, Leipzig, Berlin 1897-] 10, s. 266; O modlitwie 7, GCS 2, s. 216.

${ }^{17} \mathrm{O}$ modlitwie 7, GCS 2, s. 216.

${ }^{18} \mathrm{O}$ zasadach I, 7, 2, GCS 22, s. $86 \mathrm{n}$. 
oparcia w tradycji teologicznej ${ }^{19}$. Skłonny jest nawet przypisywać tym ciałom posiadanie specjalnej asystencji aniołów Bożych, którzy przekazują im od Stwórcy moc trwania w ich kosmicznym ruchu. W ramach swojego systemu teologicznego, który ogarnia także prawa ugwieżdżonego nieba, Orygenes niejednokrotnie wyrażał myśl, że słońce i księżyc uczestniczą na mistyczny sposób także w grzechu, który dokonuje się w świecie ${ }^{20}$, i z tej racji obydwa ciała niebieskie wraz $\mathrm{z}$ "całym stworzeniem wyczekują odnowienia synów Bożych" (Rz 8, 19) ${ }^{21}$. Dlatego chrześcijanie - choć sobie $\mathrm{z}$ tego nie w pełni zdają sprawę - patrzą z głębokim szacunkiem religijnym na te ciała niebieskie, przedziwne dzieła Boga, pełniące jedyną w swoim rodzaju funkcję w świecie. Skoro i na nich, według sformułowania Pawła Apostoła, odbił się grzech człowieka, , ,jęk stworzenia" (Rz $8,22)$, to i one logicznie uczestniczą również $\mathrm{w}$ dobrodziejstwie daru odkupienia, wyśpiewując sobą hymn uwielbienia Bogu wszechświata przez Jednorodzonego, Odwieczne Słowo, i w mistyczny sposób służą również człowiekowi w przeżywaniu dzieła odkupienia.

W duchu tej mistyki kosmosu staje się zrozumiałe, że Orygenes dostrzega w naturze i w ruchach ciał niebieskich znaki ustanowione według odwiecznych zamysłów Stwórcy, które kierują uwagę człowieka na ową „wielką tajemnicę”. Księżyc jest da niego „królową nieba”22 oświetloną przez światłość zawsze jaśniejącego Boskiego Logosu, „prawdziwego słońca". Z tej racji księżyc może przybierać charakter symbolu Kościoła. To pozwala mu wyprowadzać konsekwentnie dalsze treści symbolizmu tajemnicy Kościoła ożywającego w blasku światłości i na przemian zaciemnianego złem, przez co doświadcza duchowego umierania.

Niezwykły autorytet Orygenesa niewątpliwie miał wpływ na przejęcie tematyki księżyca jako symbolu Kościoła w powiązaniu z Chrystusem. Można tu mówić w pewnym sensie o początkach tradycji teologii „lunarnej” Kościoła ${ }^{23}$ (luna - księżyc), która będzie się z biegiem czasu pogłębiać zwłaszcza w Kościele zachodnim. To, co u Teofila z Antiochii było tajemnicą "Boga i człowieka”, w szkole aleksandryjskiej ewoluuje w kierunku tajemnicy "Chrystusa i Kościoła”, w której zawarte są wszelkie inne aspekty Kościoła. „Jak o słońcu i księżycu mówi się, że są

\footnotetext{
${ }^{19}$ Por. H. Rahner, L'ecclesiologia dei Padri, s. 172.

${ }^{20}$ Orygenes, $\mathrm{O}$ zasadach I, 7, 4, GCS 22, s. 87.

${ }^{21}$ Tamże.

${ }^{22} \mathrm{~W}$ jęz. greckim Selene (księżyc) jest rodzaju żeńskiego, co ułatwiało taką lekturę.

${ }^{23}$ H. Rahner, L'ecclesiologia dei Padri, s. 173.
} 
wielkimi światłami na firmamencie nieba, tak dla nas jest tym Chrystus i Kościół”24. Takie podejście otwiera Orygenesa na kolejne rozważania o „niebie naszych serc”25, czyli o królestwie Boga, którego figura, niedoskonałym obrazem jest firmament niebieski. Na nim jaśnieją dwa wielkie ciała: słońce i księżyc, tj. Chrystus i Kościół. Odbiciem natomiast światła księżyca są gwiazdy - Apostołowie. „Jak bowiem słońce i księżyc oświecają nasze ciała, tak Chrystus i Kościół oświecają nasze umysły" ${ }^{\prime 26}$. Jest to porządek stały, nienaruszalny przez człowieka, napełnionym duchowym pokojem kosmosu. Chrystus jest słońcem, Kościół - księżycem, Apostołowie - gwiazdami. Ku nim się zwraca ciemna ziemia naszych dusz, oświetlona na miarę szukania przez nich Bożej światłości. W tajemniczym kosmosie życia wewnętrznego człowieka niejako odzwierciedla się los Kościoła "zamierającego” i "ożywającego” jak księżyc²7.

W zmierzaniu księżyca ku swojemu zanikowi, ale połączonemu ożywiającą jednością ze słońcem, Orygenes dostrzegał ilustrację fundamentalnej prawdy wiary, według której Kościół „zaciemniany i rozjaśniany”, brany w swej całości, zmierza ku dopełnieniu swoich czasów, czyli do tego momentu, kiedy Chrystus, Słońce sprawiedliwości, rozbłyśnie pełnią blasku swej chwały. Wtedy w tym świetle zaniknie. Światłość Kościoła będzie zbędna, gdyż będzie on się cieszył wytęsknioną światłością swojego Oblubieńca. Podobnie dusza chrześcijańska, mikrokosmos duchowego świata, może jednocześnie dostrzegać w księżycu - Kościele figurę swojego przeznaczenia w dążeniu ku jedności z Ojcem w Chrystusie. Jest to droga poprzez ciemności, cierpienia i wyrzeczenia, która prowadzi do chwalebnego zwycięstwa. Taki właśnie kierunek został wytyczony do podążania za Chrystusem, zarówno dla Kościoła jako całości, jak i dla poszczególnych dusz ${ }^{28}$.

\section{NOWA POSTAĆ TEMATU W EKLEZJOLOGIl AMBROŻEGO}

Aleksandryjska tradycja „lunarnej” teologii Kościoła „umierającego i ożywającego", znalazła swoją kontynuację nie pośród teologów wyro-

${ }^{24}$ Orygenes, Homilie di Ksiegi Rodzaju I, 7, GCS 6, s. 8: „Sicut sol et luna magna luminaria dicta sunt esse in firmamento caeli, ita et in nobis Christus et Ecclesia".

${ }^{25}$ Tamże.

${ }^{26}$ Orygenes, Homilie di Księgi Rodzaju I, 7, GCS 6, s. 8: „Sicut autem sol et luna illuminant corpora nostra, ita et a Christo atque Ecclesia illuminantur mentes nostrae".

${ }^{27}$ H. Rahner, L'ecclesiologia dei Padri, s. 174.

${ }^{28}$ Por. J. M. Dermott, Lune - symbolisme releigieux, DSAM 9, kol. 1192. 
słych ze szkoły egzegezy orygenesowskiej, ale w biskupie Mediolanu, św. Ambrożym (339-397), za sprawą którego utrwaliła się w myśli Kościoła zachodniego, i gdzie przetrwała aż do późnego Średniowiecza. W przypadku Ambrożego za podjęciem tematyki dodatkowo przemawiały racje natury apologetycznej. Był to bowiem czas wzmożonej działalności ideologicznej dotychczasowych religii rzymskich, podejmowanej w Imperium, by zatrzymać oddziaływanie chrześcijaństwa. Dawna ideologia w tym okresie na nowo eksponowała kult bóstwa „Niezwyciężonego Słońca" (Solis invicti) i macierzyńskiego bóstwa Księżyca (Luna - Selene). Kult ten, usilnie szerzony w poprzednim stuleciu za sprawą cesarza Aureliana (270-275), który patronował wybudowaniu w Rzymie monumentalnej bazyliki Natalis Invicti - „Narodzenia Niezwyciężonego Słońca" z głównymi obrzędami kultowymi, które przypadały na dzień 25 grudnia ${ }^{29}$, w połowie IV stulecia znów otrzymał bardzo znaczące wsparcie legislacyjne i administracyjne ze strony Juliana Apostaty (262-263). Było to $\mathrm{w}$ sumie poważnym zagrożeniem dla wchodzącej $\mathrm{w}$ życie Imperium nowej religii, osłabionej na domiar przez trwającą całe dziesięciolecia herezję arianizmu, a tak samo zaniżeniem poziomu życia moralnego z powodu napływającej do Kościoła fali neofitów - do niedawna wyznawców kultów pogańskich - których formacja chrześcijańska nie posiadała jeszcze należytej głębi. Przeciwstawiając się odradzanemu kultowi bóstwa słońca, chrześcijaństwo łacińskie zmierzało w kierunku wprowadzenia w dniu 25 grudnia swojego nowego święta. W miejsce Natalis Invicti mówiło się teraz o dniu narodzin prawdziwego słońca świata, które rozproszyło mroki ludzkości, Jezusa Chrystusa ${ }^{30}$. Nie było zatem czymś przypadkowym tak usilne uwydatnianie przez Ambrożego w hymnach liturgicznych i homiliach motywów prawdziwego Słońca Chrystusa, czy rozwijanie wokół symboliki księżyca myśli o Kościele tracącym swoją jasność a jednocześnie nieustannie odnawiającym się przez nowe rodzenie się, zmartwychwstawanie moralne dzięki światłu swojego Słońca - Chrystusa. Przy takiej lekturze symboliki jedności księżyca ze słońcem w sposób naturalny wypływała również problematyka moralna i ascetyczna. Ta figura będzie mówiła o chrześcijaninie doświadczającym codziennego zmagania „światłości z ciemnością”, który podejmuje wy-

${ }^{29}$ Por. V. Saxer, Festa di Natale, DPAC [Dizionario Patristico e di Antichità cristiane, Casale Monferrato 1983-] 2, kol. 2346 n.

${ }^{30}$ J. Noiville, Les origines du Natalis invicti, "Revue des études anciennes" 38 (1936) s. 145 n. 
siłek moralny ku nowemu odradzaniu się, zmartwychwstawaniu przy swoim zwycięskim Słońcu ${ }^{31}$.

Zestawiając wiodące linie wizji teologicznej Ambrożego odnośnie do lunarnej figury „Kościoła umierającego i odradzającego się”, najszerzej podejmowane w jego komentarzu do biblijnego hymnu o sześciu dniach stworzenia $^{32}$, można wskazać następujące punkty.

a) "Cierpienia” księżyca wyrażające się w gaśnięciu jego światłości są przede wszystkim dla biskupa Mediolanu obrazem kluczowej dla chrześcijaństwa tajemnicy Wcielenia i kenozy Logosu. Zbawiciel przemawia również językiem kosmosu o swoim prawie odkupienia. Ambroży wyraził to na charakterystyczny dla niego sposób lirycznej prozy, we fragmencie z IV części wspominanego komentarza, który uważany jest za jeden $\mathrm{z}$ najznakomitszych tekstów łacińskich o teologii „umierania Kościoła”. W przekładzie literalnym, pozwalającym bardziej skupić się na treści, brzmi jak następuje: „Księżyc pomniejsza się, by napełnić życie elementów - Jest to zatem wielka tajemnica Sprawił to Ten, który wszystkim rozdzielił łaskę - pomniejszał go, aby znów na nowo go wypełnić - Czyni to Ten, który samego siebie wyniszczył - Wyniszczył się, aby zstąpić aż do nas - Zstąpił do nas, by stać się wstępowaniem dla wszystkich - Tak księżyc zapowiada tajemnicę"

b) W tajemnicy uniżenia się Słowa, Jego zstąpienia poprzez Wcielenie, zawarta jest również tajemnica Kościoła. Od momentu Wcielenia Kościół jest „umiłowanym Kościołem”, „oblubienica”, która jako jedyna towarzyszy „niebieskiemu bratu” - słońcu. Jako duchowy księżyc, Kościół przemierza noc życia ziemskiego, a w swoim pomniejszaniu, tj. „zamieraniu” naśladuje uniżenie Oblubieńca, gdyż los Kościoła jest złączony z Jego losem. Będzie on trwał w tym "zamieraniu” aż do dnia, kiedy zostanie w pełni ogarnięty światłością Logosu, gdy spełnią się w nim słowa: „żyję już nie ja, ale żyje we mnie Chrystus”.

${ }^{31}$ H. Rahner, L'ecclesiologia dei Padri, s. 206 n.

${ }^{32}$ Ambroży, Hexaemeron IV, 1-8, CSEL [Corpus scriptorum Ecclesiasticorum Latinorum, Wien 1866-] 32, s. 109 nn.

${ }^{33}$ Ambroży, Hexaemeron IV, 8, CSEL 32, s. 137: "Minuitur Luna, ut elementa repleat - Hoc est ergo grande mysterium - Donavit hoc ei qui omnibus donavit gratiam - Exinanivit eam ut repleat - Qui etiam se exinanivit ut omnia impleret - Exinanivit Se ut descenderet nobis - Descendit nobis ut ascenderet omnibus [...] - Ergo annuntiavit Luna mysterium Christi". 
W ten sposób nasz teolog może powiedzieć: „Nie jest błahą sprawą, że Chrystus wybrał księżyc na symbol, przez który będzie wyrażał obraz umiłowanego Kościoła. Kościół nie bez racji ukazywany jest na podobieństwo księżyca. On tak samo rozjaśnia się blaskiem przed całym światem, a rozświetlając ciemności obecnego czasu, daje usłyszeć swój głos w słowie Pisma: „Noc przeminęła i przybliżył się dzień" ${ }^{34}$. Skoro przemierza drogi nieba w ciemnościach, Kościół też musi dzielić los doświadczania "ciemności”, "cierpienia umierającego" księżyca ${ }^{35}$.

c) Słońce i księżyc przybierają charakter symbolu nierozdzielnej więzi Chrystusa z Kościołem, który swoją światłość i moc czerpie od Chrystusa. W oratorskim uniesieniu Ambrożego, kantyk ku czci Chrystusa - Słońca przemienia się zaraz w hymn o Kościele: „On jest prawdziwym księżycem, który od niezachodzącej światłości bratniej gwiazdy jest odmieniany blaskiem nieśmiertelności i łaski. Kościół bowiem rozbłyska nie własnym światłem, ale światłem Chrystusa i czerpie swój splendor od słońca sprawiedliwości, aby mógł powiedzieć: „żyję ja, już nie ja, ale żyje we mnie Chrystus". Prawdziwie szczęśliwy jesteś księżycu, który stałeś się godny takiego zaszczytu"36. Można by tutaj dodać, że w kulturze języka łacińskiego, gdzie luna jak i ecclesia są rodzaju żeńskiego, identyfikacja Kościoła z księżycem jest o wiele bardziej narzucająca się, niż języku polskim.

d) W Kościele „zamierającym” i odzyskującym światłość urzeczywistnia się tajemnica mistycznej śmierci, która prowadzi do zmartwychwstania. To ciągłe „umieranie" i zmartwychwstawanie dokonujące się w Kościele, jest wielkim pielgrzymowaniem do wiecznej Paschy. W charakterystycznym dla siebie języku mistyki chrześcijańskiej i poezji Ambroży będzie mówił: „Kościół ogarnięty jest jeszcze mrokiem, ale jest to mimo wszystko mrok zbawienia, cień, który z ciała Chry-

${ }^{34}$ Ambroży, Hexaemeron IV, 8, CSEL 32, s. 138: „Non mediocris [luna] in qua signum posuit suum, quae typum habet dilectae Ecclesiae [...] et merito sicut luna Ecclesia, quae toto mundo refulsit et tenebra saeculi huius illuminans dicit: nox praecessit, dies adpropinquavit".

${ }^{35}$ H. Rahner, L'ecclesiologia dei Padri..., s. 212; J. M. Dermott, Lune - symbolisme releigieux, DSAM 9, kol. 1193.

${ }^{36}$ Ambroży, Hexaemeron IV, 8, CSEL 32, s. 138: „Haec est vera luna, quae de fraterni sui luce perpetua sibi lumen immortalitatis et gratiae mutatur. Fulget enim Ecclesia non suo, sed Christi lumine et splendorem sibi arcessit de Sole iustitiae, ut dicat: vivo autem iam non ego, vivit autem in me Christus. Beata plane, quae tantum insigne meruisti". 
stusa i Jego krzyża pada na Kościół, przykrywając sobą światło przyszłego zmartwychwstania"37. Można przypuszczać, że gdy Ambroży podejmował ten wątek tematyczny, miał przed oczami paralelny obraz z mitologii rzymskiej, gdzie świat pogański mówił o księżycu jako o świetlistej bogini, która na kwadrydze ciągnionej majestatycznie przez woły, powoli przemierza przestrzeń nocnego nieba, wznosząc się ku wysokościom. Z takiego bowiem kontekstu obrazów wywodzi się sformułowanie: „Chrystus jest jak taurus (wół, byk), dzięki któremu Kościół jest symbolizowany przez księżyc tym pełniej, kiedy jakby rogami usiłuje objąć przestrzeń całego świata"38.

\section{FIGURA UGRUNTOWANA W NAUCZANIU PASTORALNYM AUGUSTYNA}

Augustyn (354-430) zafascynowany doktryną Kościoła, którą odczytywał przez pryzmat egzegezy ojca swojej wiary, Ambrożego, przejął od niego również metaforykę Kościoła „umierającego” wyrażaną poprzez symbolikę księżyca. W odróżnieniu od swojego nauczyciela wiary, wydaje się, że jeszcze bardziej ją osadził w kontekście liturgiczno-paschalnym, a jednocześnie w bardziej przystępny i praktyczny sposób przeniósł ją na pole przepowiadania pastoralnego.

Punktem wyjścia w tych rozważaniach była zawsze dla Augustyna tajemnica paschalna, pojmowana jako absolutnie centralny punkt życia chrześcijańskiego. Chrześcijanin raz ogarnięty przez zbawcze tajemnice paschalne Chrystusa, czyni tę drogę programem całego swojego życia. Jest ono niczym innym, jak ciągłym „przechodzeniem” - taki jest sens Paschy - ze śmierci do życia, które dokonuje się w głębi ducha człowieka. Tajemnica życia, które wypływa ze śmierci, urzeczywistnia się w świętości duszy. W taki sposób Kościół prowadzony do splendoru paschalnej „pełni księżyca” „przechodzi”, czyli przybiera swe różne formy istnienia w duszach, od "ciemnych” do naznaczonych jasnością bliskości Boga. Tajemnica paschalna przybiera w ten sposób postać „trwania razem ze

${ }^{37}$ Ambroży, Hexaemeron IV, 8, CSEL 32, s. 139: „Umbra quidem, quia corporis est, umbra, quia crucis, sed umbra salutis, quia in ea erat peccatorum remissio et resuscitatio mortuorum".

${ }^{38}$ Ambroży, De Patriarchis III, 13, CSEL 32-2, s. 131: "Christus est taurus quo Ecclesia figuratur in luna tunc plenior, cum velut cornibus nixi taurinis spatium totius orbis includit". H. Rahner, L'ecclesiologia dei Padri, s. 214-216. 
Słońcem" (permanere cum Sole), które jest przewyższeniem, wyzwoleniem się ze stanu wyrażanego przez "szaloną zmienność księżyca"39. Można powiedzieć, że mistyczna eklezjologia „lunarna”, w odróżnieniu od egzegezy moralnej Ambrożego, jest teraz przenoszona do całokształtu augustyńskiej wizji tajemnicy zbawienia.

Należałoby tu jeszcze mieć przed oczami, że Augustyn posługuje się takim rozumieniem księżyca, jakie mu umożliwiał ówczesny stan wiedzy astronomicznej, określony przez geocentryzm i uwrażliwienie na tę tematykę wyniesione $\mathrm{z}$ długich, dziewięcioletnich doświadczeń manichejskich. Odbiciem tego jest choćby przekonanie Augustyna, że w czasie swoich faz księżyc powiększa się: jego światło wzrasta wtedy, gdy oddala się od słońca, a pomniejsza się, gdy zbliża się do słońca z drugiej strony. Na płaszczyźnie symboliki teologicznej to mu pozwala mówić, że księżyc - Kościół zbliżając się do Chrystusa, prawdziwego słońca, "ginie w Chrystusie", ale nie w sensie zatracenia swojej tożsamości, lecz w znaczeniu, że jego światłością jest teraz całkowicie Chrystus ${ }^{40}$. Tematyka ta została podjęta przede wszystkim w Liście 55 z 401 r., adresowanym do Januarego, z którym już wcześniej prowadził korespondencję na temat wykładu prawd wiary ${ }^{41}$.

W wypowiedzi Augustyna, odnośnie do eklezjologicznego motywu księżyca rysują się następujące myśli² ${ }^{42}$ Dla chrześcijan temat księżyca jest elementem bardzo ważnym, gdyż z jego wiosennym przesileniem łączy się data obchodzenia Paschy, gdzie nie chodzi tylko o zwykłe wspominanie dnia śmierci i zmartwychwstania Chrystusa, ale o osobiste uczestniczenie w "przejściu” ze śmierci do życia. W mysterium lunae odzwierciedla się w pewien sposób tajemnica paschalna przeżywana przez chrześcijanina, co jednocześnie osadzone jest w tajemnicy Chrystusa i Kościoła. W przypadku poszczególnych chrześcijan dokona się ono w pełni dopiero na końcu czasów Kościoła, gdy zakończy się jego okres pielgrzymowania. Niemniej jednak dokonuje się już w nich proces ustępowania człowieka "zewnętrznego" na rzecz powstawania, rodzenia się światła człowieka „wewnętrznego"43.

${ }^{39}$ Augustyn, Epistula 55, 5, 8, CSEL 34-2, s. 178.

${ }^{40}$ Por. Epistula 55, 4, 7, CSEL 34-2, s. 176 n.

${ }^{41}$ Zob. A. Fitzgerald, Tavola delle «Epistulae», Agostino. Dizionario enciclopedico, Roma 2007, s. 69.

${ }^{42}$ Por. A. Clerici, Sant'Agostino. La Chiesa da Eva, Roma 2000, s. 48-50.

${ }^{43}$ Por. Augustyn, Epistula 55, 1, 2, CSEL 34-2, s. 171. Por. J. M. Dermott, Lune - symbolisme releigieux, DSAM 9, kol. 1193. 
Dla Augustyna, tak jak dla jego poprzedników, słońce jest symbolem Chrystusa a w księżycu widzi zarówno symbol człowieka (Adama) w jego stanie egzystencjalnym wobec Boga po grzechu pierworodnym, jak również figurę całego Kościoła. Augustyn wyjaśnia, że dusza człowieka odrywa się od rzeczy ziemskich, do których się zbliżyła po swoim oddaleniu od „słońca sprawiedliwości”, Chrystusa, i zaczyna powracać do niezmiennej mądrości, żeby coraz bardziej „umierać” dla takiego życia i ukryć się z Chrystusem w Bogu ${ }^{44}$.

Po przyjęciu takich założeń Augustyn przystępuje teraz do lektury mysterium według klucza eklezjologicznego. Przestrzenia, w której realizuje się tajemnica przyjmowania od Chrystusa daru odkupienia jest Kościół. Dlatego w tym kontekście Augustyn może stwierdzić, że Kościół, będąc jeszcze na etapie, kiedy człowiek podlega ułomności moralnej i śmierci, jest ukazywany w Piśmie świętym poprzez obraz księżyca ze względu na zmienność ludzkich postaw. Kościół zatem jest jednocześnie ciemny i rozbłyskający światłem. Tak będzie aż do dnia, gdy „księżyc zagaśnie” (Ps 71, 7), czyli kiedy osiągnie pełnię pokoju w niebieskim Jeruzalem ${ }^{45}$.

Tematyka eklezjologiczna w oparciu o motyw księżyca pojawi się jeszcze kilkakrotnie w komentarzach do Psalmów, odsłaniając jeszcze inne treści, które sugerują mu optyczne zmiany intensywności świata księżyca. Obraz księżyca do połowy zaciemnionego i w połowie oświetlonego, wskazuje Augustynowi - podobnie jak i innym egzegetom - na to, że Kościół (księżyc) otrzymuje światłość od Chrystusa, swojego słońca ${ }^{46}$. Słońce i księżyc stanowią obraz jednej tajemnicy Chrystusa i Kościoła, tak że cielesna śmierć Chrystusa dokonuje się mistycznie w ciele Kościoła ${ }^{47}$. Zachód słońca, czyli tajemnica ukrzyżowania Chrystusa, zbiega się z pojawieniem się na niebie księżyca, Kościoła. W nim przedłużają się na wieki śmiertelne cierpienia Chrystusa. Słońce jednak, które zaszło, nie zagasło, nie zakończyło swego istnienia, podobnie jak i księżyc, który także nie zagaśnie, gdy będzie na nowo blisko swego słońca ${ }^{48}$. W kontekście takiego rodzaju symboliki nie mógł ujść uwagi naszego autora detal, że „zamierający" księżyc pozostaje niewidzialny przez trzy dni, by potem otworzyć

${ }^{44}$ Augustyn, Epistula 55, 5, 8, CSEL 34-2, s. 178: "ut magis magisque huic saeculo moriatur, et vita eius abscondatur cum Christo in Deo".

${ }^{45}$ Por. Augustyn, Epistula 55, 6, 10, CSEL 34-2, s. 180.

${ }^{46}$ Por. Augustyn, Enarratio in Ps. 10, 3-4, CCL 38, s. 75 n. H. Rahner, Ecclesiologia dei Padri, s. 220 nn.

${ }^{47}$ Por. Augustyn, Enarratio in Ps. 120, 12, CCL 40, s. 1798.

${ }^{48}$ Por. Augustyn, Enarratio in Ps. 134, 19-20, CCL 40, s. 1951 nn. 
się na drogę wzrastania w światłości, co sugestywnie naprowadzało na tematykę "trzeciego dnia” zmartwychwstania kontynuowanego w życiu Kościoła. Pełni zmartwychwstania doświadczy on wtedy, gdy zostanie ogarnięty przez wieczną światłość Boga, nie posiadając w sobie już nic ze zmienności podlegającej śmierci, ale w tym samym czasie rozbłyśnie swą pełnią, istniejąc jako Kościół, który króluje na zawsze z Chrystusem ${ }^{49}$.

Tytułem krótkiego dopowiedzenia do powyższego szkicu o liniach wiodących starożytnej eklezjologii lunarnej, można zaznaczyć, że ta problematyka była kontynuowana także w kolejnych stuleciach, do Średniowiecza włącznie, tak przez autorów zachodnich jak i wschodnich. Przy czym charakterystycznym rysem będzie stopniowe poszerzanie jej o symbolizm maryjny, dla którego oparciem był zwłaszcza tekst z 12 rozdziału Apokalipsy o „niewieście obleczonej w słońce i z księżycem pod

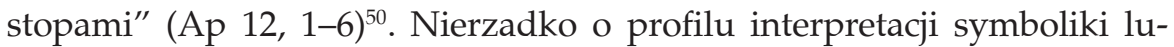
narnej decydował klimat czasów. Gdy z upływem czasu w późniejszym Średniowieczu radykalizowała się postawa chrześcijaństwa zachodniego wobec Żydów, nie było zaskoczeniem, że pojawiły się również tendencje, by widzieć w słońcu symbol tryumfującego Kościoła nad Synagogą identyfikowaną z gasnącym regularnie księżycem, który ma racje istnienia tylko przy słońcu ${ }^{51}$. Z pewnością interesującą sprawą byłoby prześledzenie zagadnienia również na płaszczyźnie bogatej średniowiecznej ikonografii tematyki słońca i księżyca. Kwestie te jednak dla rzetelności ich przedstawienia domagają się szerszego, oddzielnego studium.

Niniejsze opracowanie, przybliżając wybrane aspekty starożytnej myśli soteriologicznej związane ze symboliką słońca i księżyca, odsłaniało sposób wyrażania tajemnic wiary, właściwy tamtym czasom. Odczytywanie ich w kontekście swojej kultury zawsze tworzyło pewną niepowtarzalną specyfikę na płaszczyźnie języka komunikowania objawionych prawd wiary. Każda epoka bowiem żyje swoim światem pojęć i posiada swój język zakorzeniony w kulturze danych czasów. Odwołanie się do symbolizmu ze świata astralnego pozwalało wielkim starożytnym teologom Kościoła przekonująco a jednocześnie bez ryzyka nieporozu-

${ }^{49}$ Por. Augustyn, Enarratio in Ps. 71, 10, CCL 39, s. 979. A. Clerici, Sant'Agostino. La Chiesa da Eva, s. 49-50.

${ }^{50}$ Por. J. M. Dermott, Lune - symbolisme releigieux, DSAM 9, kol. 1195.

${ }^{51}$ Por. D. Forstner, dz. cyt., s. 100 n. 
mień, naświetlać treści wiary dotyczące Chrystusa, tajemnic paschalnych, Kościoła a kolejno i obecnej w nim Maryi, miejsca cierpienia i śmierci w ekonomii zbawienia i jej chwalebnego końca. Choć dzisiaj ta symbolika już nie przemawia z tak żywą siłą argumentowania jak w starożytności, niemniej jest $w$ niej element trwały: mówi o metodzie, o postawie nieustannego poszukiwania najwłaściwszego języka dla komunikatywnego formułowania i przepowiadania tajemnic zbawienia. Za tym z jednej strony stało oddanie dziełu ciągłej ewangelizacji, a z drugiej głęboka znajomość ewangelizowanego środowiska i szacunek dla jego kultury. To sprawiało, że starożytni teologowie nie obawiali się budować wielkiej mozaiki symboliki chrześcijańskiej, sięgając do symbolizmu natury a także do terminologii ówczesnych nauk przyrodniczych.

\section{IL MOTIVO DEL "MYSTERIUM LUNAE" NELL'ECCLESIOLOGIA DELLA CHIESA PRIMITIVA}

\section{RIASSUNTO}

Lo studio prende in esame un tema ecclesiologico del periodo della Chiesa dei primi secoli, espresso con il motivo attinto dalla simbologia astrale, quale è il tema del sole e della luna, con cui si esprimeva il mistero della congiunzione di Cristo con la Chiesa in aspetto soterico. La nostra attenzione sta puntando prima sul dare lo sfondo culturale della problematica, per presentare successivamente come questo tema veniva approfondito nel corso del processo di formazione del linguaggio teologico cristiano. Vi si prendono in considerazione le tappe legate agli ambienti di teologi Apopogisti del II secolo, quindi di Origene, Ambrogio ed Agostino, cioé, gli ambienti dove il tema assunse le espressioni pio̊ mature. La figura del sole e della luna ripresa dalla simbolica di natura, vivamente presente nella mentalità e cultura antica, ora ricevette presso i grandi teologi cristini una nuova interpretazione, che permetteva orientare l'attenzione dei neofiti al mistero di Cristo e della Chiesa. Sicuramente non rimaneva senza significato il dato che il motivo di entrambi i corpi astrali apparteneva al linguaggio biblico, ciò che incoraggiava a rileggerlo in quanto segno voluto dal Creatore con il suo proprio contenuto semantico nell'ambito dell'economia della salvezza. 